Supplement of Web Ecol., 16, 3-5, 2016

http://www.web-ecol.net/16/3/2016/

doi:10.5194/we-16-3-2016-supplement

(C) Author(s) 2016. CC Attribution 3.0 License.

(c) (i)

Supplement of

\title{
Effects of agricultural practices on soil and microbial biomass carbon, nitrogen and phosphorus content: a preliminary case study
}

\author{
F. Amaral and M. Abelho \\ Correspondence to: M. Abelho (abelho@esac.pt)
}

The copyright of individual parts of the supplement might differ from the CC-BY 3.0 licence. 


\section{Methods}

\section{Study sites}

Table S1 Description of the four soil plots located at Coimbra, central Portugal

\begin{tabular}{|c|c|c|c|c|c|}
\hline $\begin{array}{l}\text { Study } \\
\text { plot }\end{array}$ & $\begin{array}{l}\text { Farming } \\
\text { management }\end{array}$ & $\begin{array}{l}\text { Previous } \\
\text { culture }\end{array}$ & Fertilization & $\begin{array}{l}\text { Current } \\
\text { culture }\end{array}$ & $\begin{array}{l}\text { Geographic } \\
\text { coordinates }\end{array}$ \\
\hline OF1 & Organic & Lucerne & Lucerne green manure & Corn & $40^{\circ} 13^{\prime} 03^{\prime \prime} \mathrm{N}, 8^{\circ} 26^{\prime} 51^{\prime \prime} \mathrm{W}$ \\
\hline OF2 & Organic & Corn & Organic compost & Corn & \\
\hline OF3 & Organic & Corn & None & Corn & \\
\hline $\mathrm{CF}$ & Conventional & Corn & Chemical fertilizer & Corn & $40^{\circ} 13^{\prime} 14^{\prime \prime} \mathrm{N}, 8^{\circ} 28^{\prime} 36^{\prime \prime} \mathrm{W}$ \\
\hline
\end{tabular}

\section{Soil preparation and analysis}

For soil physic-chemical characterization, nine random core samples $\left(0-20 \mathrm{~cm} ; 250 \mathrm{~cm}^{3}\right)$ were collected in each of the four plots and bulked to produce a composite sample per plot. The samples were homogenized, oven-dried $\left(28^{\circ} \mathrm{C}\right.$ with ventilation, $\left.24 \mathrm{~h}\right)$, grounded and sieved $(2 \mathrm{~mm})$ to separate the fine particle fraction for analysis. Soil moisture was determined gravimetrically after drying at $105^{\circ} \mathrm{C}$ for $24 \mathrm{~h}$, textural fractions (coarse sand: 2-0.2 mm; fine sand: 0.2-0.02 mm; silt: 0.02-0.002 mm; clay: $<0.002 \mathrm{~mm}$ ) were separated by sedimentation, soil $\mathrm{pH}$ was measured in water $(1: 2.5)$. Total organic carbon was quantified as $\mathrm{CO}_{2}$ by infrared absorption spectrophotometry (Leco SC-144 DR) after combustion at $590^{\circ} \mathrm{C}$ (Rossell et al., 2001). Phosphorus pentoxide $\left(\mathrm{P}_{2} \mathrm{O}_{5}\right)$ and potassium oxide $\left(\mathrm{K}_{2} \mathrm{O}\right)$ were extracted with the Egnér-Riehm method (Balbino, 1968) and quantified by colorimetry after molecular absorption spectrophotometry $\left(\mathrm{P}_{2} \mathrm{O}_{5}\right.$; Philips PYE Unicam SP6-350) and atomic absorption spectrophotometry with a flame atomizer $\left(\mathrm{K}_{2} \mathrm{O}\right.$; Perkin Elmer Analyst 300). Total Kjeldahl nitrogen (ammonia $\left(\mathrm{NH}_{3}\right)$, ammonium $\left(\mathrm{NH}_{4}{ }^{+}\right)$, and organic nitrogen) was quantified with the Bremmer method (Bremmer, 1979). The exchange cations $\mathrm{K}^{+}, \mathrm{Na}^{+}, \mathrm{Ca}^{2+}$ and $\mathrm{Mg}^{2+}$ were quantified by atomic absorption spectrophotometry with a flame atomizer (Chapman, 1979).

\section{Soil and microbial biomass CNP extraction and quantification}

Microbial biomass $\mathrm{C}, \mathrm{N}$ and $\mathrm{P}$ were assessed by the chloroform fumigation-extraction (CFE) technique (Jenkinson and Powlson, 1976; Brookes et al., 1982, 1985a, 1985b; Vance et al., 1987). The composite samples were homogenized; sieved $(2 \mathrm{~mm})$ and all visible organic fragments were removed. Moisture was determined as the difference between fresh mass and 
oven-dry mass $\left(105^{\circ} \mathrm{C}, 24 \mathrm{~h}\right)$. The samples $(100 \mathrm{~g})$ were brought to $50 \%$ field water holding capacity and four subsamples of $25 \mathrm{~g}$ were allocated to $250 \mathrm{~mL}$ individual vials. One $\mathrm{mL}$ chloroform $\left(\mathrm{CHCl}_{3}\right)$ was added to two subsamples (fumigation); the vials were hermetically closed and incubated in a dark oven (Cassel EI-3) at $25^{\circ} \mathrm{C}$ during $24 \mathrm{~h}$. Four additional samples incubated in the same conditions but without soil were used as controls. All samples were evaporated under an extraction hood for $6 \mathrm{~h}$ to allow total elimination of the chloroform (Brookes et al., 1982). From each subsample, $2 \mathrm{~g}$ of soil were used to determine phosphorus and $23 \mathrm{~g}$ were used to determine organic carbon and nitrogen.

Phosphorus was extracted by adding $30 \mathrm{~mL}$ of $0.5 \mathrm{M}$ sodium bicarbonate $\left(\mathrm{NaHCO}_{3} ; \mathrm{pH}\right.$ $8.5)$ to the $2 \mathrm{~g}$ of soil, the sample was agitated (180 rpm, $1 \mathrm{~h})$ and decanted $(1 \mathrm{~h})$. The supernatant was filtered (filter paper) and $2 \mathrm{~mL}$ of $10 \mathrm{M}$ hydrochloric acid $(\mathrm{HCl})$ were added to destroy humic material. The mixture was agitated for 30 minutes and filtered again to separate the humic acids (Olsen \& Sommers, 1982). Phosphorus was quantified by colorimetry using the method described by Murphy \& Riley (1962). Color intensity was measured on a molecular absorption spectrophotometer (Philips PYE Unicam SP6-350) at $782 \mathrm{~nm}$. Standard phosphate solutions $\left(0,0.25,0.5,1.0,1.5\right.$ and $\left.2.5 \mathrm{mg} \mathrm{P} \mathrm{L}^{-1}\right)$ were prepared as above and a calibration curve, obtained from the linear regression between the concentration of $\mathrm{P}$ in the standard and absorbance $\left(\mathrm{r}^{2}=0.998\right)$ was used to quantify $\mathrm{P}$ in the samples.

Carbon and nitrogen were extracted by adding $70 \mathrm{~mL}$ of $\mathrm{K}_{2} \mathrm{SO}_{4} 0.5 \mathrm{M}$ to the $23 \mathrm{~g}$ subsample, the mixture was agitated $(180 \mathrm{rpm}, 1 \mathrm{~h})$, decanted $(1 \mathrm{~h})$, the supernatant was filtered (filter paper) and the extract was kept at $4^{\circ} \mathrm{C}$.For carbon determination, $8 \mathrm{~mL}$ of the extract were digested at $100^{\circ} \mathrm{C}$ during 45 minutes in $2 \mathrm{~mL} \mathrm{~K}_{2} \mathrm{Cr}_{2} \mathrm{O}_{7} 0.066 \mathrm{M}, 10 \mathrm{~mL} \mathrm{H}_{2} \mathrm{SO}_{4}$ $98 \%$ and $5 \mathrm{~mL}$ de $\mathrm{H}_{3} \mathrm{PO}_{4} 88 \%$. After cooling, $70 \mathrm{~mL}$ of deionized water and 4 diphenylamine drops $\left(\mathrm{C}_{12} \mathrm{H}_{11} \mathrm{~N}\right)$ were added and the solution was titrated with a solution of $0,033 \mathrm{M}$ $\left(\mathrm{NH}_{4}\right)_{2} \mathrm{Fe}\left(\mathrm{SO}_{4}\right)_{2} \cdot 6 \mathrm{H}_{2} \mathrm{O}$. For nitrogen determination, $20 \mathrm{~mL}$ of the extract were digested at $350^{\circ} \mathrm{C}$ during 2 hours with $5 \mathrm{mg}$ of a mixture of $\mathrm{K}_{2} \mathrm{SO}_{4}, \mathrm{FeSO}_{4} .7 \mathrm{H}_{2} \mathrm{O}$ e CuSO 4 (25:4.5:1) and $7.5 \mathrm{~mL}$ of $\mathrm{H}_{2} \mathrm{SO}_{4} 98 \%$. After cooling, the Kjeldahl nitrogen was distilled (Tecator Kjeltec System 1026), recovered in $2 \%$ boric acid in the presence of bromocresol purple $\left(\mathrm{C}_{21} \mathrm{H}_{16} \mathrm{Br}_{2} \mathrm{O}_{5} \mathrm{~S}\right)$ and methyl red $\left(\left(\mathrm{CH}_{3}\right)_{2} \mathrm{NC}_{6} \mathrm{H}_{4} \mathrm{~N}\right)$, and neutralized with $0,1 \mathrm{M} \mathrm{HCl}$. Carbon and nitrogen were quantified using Eq. (S1): 
Extracted element $\left(\mathrm{mg} \mathrm{kg}^{-1}\right)=\frac{(\mathrm{Vb}-\mathrm{Vs}) \times \mathrm{M} \times \mathrm{mEq} \times \mathrm{V} 1 \times 10^{6}}{\mathrm{DM} \times \mathrm{V} 2}$

(Equation S1)

Where: $\mathrm{Vb}$ is the volume of titrant used for the blank, $\mathrm{Vs}$ is the volume of titrant used for the sample, $\mathrm{M}$ is the molarity of the titrant, $\mathrm{mEq}$ is the milliequivalent weight of organic carbon (0.003) or nitrogen (0.014), DM is the dry mass of soil, V1 is the volume of the extractant and V2 is the volume of the sample.

Microbial carbon, nitrogen and phosphorus were assessed as the difference between the fumigated (soil and intracellular organic elements) and the non-fumigated samples (soil organic elements). All values were expressed as $\mathrm{mg}$ soil $\mathrm{kg}^{-1}$

\section{References}

Balbino, L.R.: O método de Egnér-Riehm na determinação do fósforo e do potássio assimiláveis em solos de Portugal, Revista Agronómica, 51, 46-56, 1968.

Bremmer, J. M. Total Nitrogen. In Black, C. A., Evans, D. D., White, J. L., Ensminger, L. E., and Clark, F. E. (eds.): Methods of Soil Analysis: Part 2. Chemical and Microbiological Properties. Agronomy 9. $5^{\text {th }}$ edition. American Society of Agronomy, Madison, Wisconsin, 1149-1178, 1979.

Brookes, P. C.: The use of microbial parameters in monitoring soil pollution by heavy metals, Biology and Fertility of Soils, 19, 269-279, 1995.

Brookes, P. C.; Kragt, J. F., Powlson, D. S., and Jenkinson, D. S.: Chloroform fumigation and the release of soil nitrogen: the effects of fumigation time and temperature, Soil Biology \& Biochemistry, 17, 831-835, 1985a.

Brookes, P. C., Landman, A., Pruden, G., and Jenkinson, D. S.: Chloroform fumigation and the release of soil nitrogen: a rapid direct extraction method to measure microbial biomass nitrogen in soil, Soil Biology \& Biochemistry, 17, 837-842, 1985b.

Chapman, H. D.: Total Exchangeable Bases. In Black, C. A., Evans, D. D., White, J. L., Ensminger, L. E., and Clark, F. E. (eds.): Methods of soil Analysis: Part 2. Chemical and Microbiological Properties. Agronomy 9. $5^{\text {th }}$ edition. American Society of Agronomy, Madison, Wisconsin, 1149-1178, 1979.

Jenkinson, D. S. and Powlson, D. S.: The effects of biocidal treatments on metabolism in soil. I. Fumigation with chloroform, Soil Biology \& Biochemistry, 8, 167-177, 1976. 
Murphy, J. and Riley, J.P.: A modified single-solution method for the determination of phosphorus in natural waters, Analytica Chimica Acta, 27, 31-36, 1962.

Olsen, S. R. and Sommers, L. E. Phosphorus. In Page, A. L., Miller, R. H., and Keeney, D. R. (eds.): Methods of Soil Analysis, Part 2: Chemical and Microbiological Properties. American Society of Agronomy, Soil Science Society of America, Madison, Wisconsin, 403-430, 1982. Rossell, R. A., Gasparoni, J. C., and Galantini, J. A.: Soil organic matter evaluation. In Lal, R., Kimble, J. M., Follet, R. F., and Stewart, B. A. (eds.), Assessment Methods for Soil Carbon. Lewis Publishers, USA, 105-113, 2001.

Vance, E. D., Brookes, P. C., and Jenkinson, D. S.: An extraction method for measuring soil microbial biomass-C, Soil Biology \& Biochemistry, 19, 703-707, 1987. 